\title{
Trajectories of the Internal Control System in the Management of Agricultural Organizations
}

\author{
Submitted 14/02/19, 1st revision 28/03/19, 2nd revision 30/05/19, accepted 13/06/19
}

Alekseeva I.V. ${ }^{1}$, Evstafieva E.M. ${ }^{2}$, Charaeva M.V. ${ }^{3}$, Mosentseva V.A. ${ }^{4}$

\begin{abstract}
:
Purpose: The article aims to investigate the current situation of the agricultural sector, as well as its normative-legal regulation in the Russian Federation. Currently, in the context of the economic development, the importance of the agricultural sector is undeniable.

Design/Methodology/Approach: It is necessary to determine the trajectory of the internal control system in the management of agricultural organizations, to investigate the current situation of the agricultural sector in the Russian Federation, as well as to systematize the normative regulation in the agricultural sector and to identify the groups of problems of the internal control system.

Findings: The article presents the stages of the implementation of the state policy in the field of a sustainable development of rural areas. There are identified the main directions of the development of the agricultural sector. Having analyzed the industry features in agriculture, determined by different scientists and practitioners, the authors identified features that affect the organization of the internal control system. There are analyzed and allocated enlarged groups of problems of internal control system in the agricultural organizations: normativelegal; organizational-methodical; informational; methodological; software and hardware.

Practical Implications: The results of the study can be implemented into the practice of organization, functioning and improvement of the internal control system of agricultural organizations.

Originality/Value: The main contribution of this study is to clarify and develop the theoretical and methodological aspects of the internal control system in agricultural organizations in the context of digitalization.
\end{abstract}

Keywords: Internal control system, reporting, stages, sustainable development.

JEL Codes: M 40, M 49.

Paper Type: Research article in a Special Issue dedicated to Russian Economy.

Section 8: Business and Economic Issues.

${ }^{1}$ D.Sc. in Economics, Professor of the Department of Accounting, Rostov State University of Economics, Rostov-on-Don, Russian Federation, irina-rseu@yandex.ru

${ }^{2}$ D.Sc. in Economics, Professor of the Department of Accounting, Rostov State University of Economics, Rostov-on-Don, Russian Federation.

${ }^{3}$ D.Sc. in Economics, Professor of the faculty of Management, Southern Federal University

${ }^{4}$ Post-graduate of the Department of Accounting, Rostov State University of Economics, Rostov-on-Don, Russian Federation. 


\section{Introduction}

Currently, the emergence and the development of the digital economy as Alekseeva and Mosentseva (2017) discribed "increasing the dynamism, complexity, turbulence of the external environment, the functioning of commercial organizations requires the development of reasonable information and analytical support and management, adaptation to changing conditions, improving competitiveness, neutralizing possible threats and the use of existing initiatives, focusing the benefits of the strategic development to achieve the desired results" has been a main issue in world economy.

To achieve this goal a commercial organization should use all kinds of modern tools and techniques for improving performance. The control system is one of the fundamental functions in management of a commercial organization. "In the modern world economy, one of the main tasks of enterprise management of various level is the search for ways to improve their performance" Labyntsev et al. (2017) said. The main aim of an effective internal control system is "the timely detection of deviations and implementation of adequate management measures to achieve the established purposes of the activity" (Klimenko, 2015). The need for the introduction of internal control system is due to the fact that it makes it possible to determine the real status quo in a commercial organization, to identify reserves and growth points, which ensures the effective achievement of the intended goals and tasks of management. T.M. Storozhuk pointed out that "the internal control system in the enterprise is effective if it effectively warns about the occurrence of false information, and detects the unreliability" (Storozhuk, 2006).

One of the effective tools for minimizing the risks and sustainable growth in the field of agriculture is the internal control system, which does not work properly in agricultural organizations. There are bottlenecks: in the level of professionalism of management personnel, in the quality of the development of internal regulations and standards governing the organization of the internal control system. Based on this, it is obvious that "regardless of the type and scale of the organization's activity, there should be in a focus of attention the clearly structured, streamlined, flexible and timely responsive to changes system of the accounting ( $S B U)$ and internal control (ICS)" (Miroshnichenko and Zubareva, 2015).

The purpose of this article is to investigate the theoretical and methodological aspects of the internal control system in agricultural enterprises in the context of digitalization and the development of proposals for their introduction and use for the implementation of strategies of the industry and the national economy as a whole.

\section{The Role of Public and Private Partnership (PPP) Institution in the Attraction of Financing}


In the Federal law "On accounting" № 402-FL in article 19 it is noted that a commercial organization is obliged to provide the internal control of all facts of economic life. From the content of the article the organization of the internal control should be enough to ensure reliable reflection in the accounting of the facts of economic life, as well as the formation of financial report. However, the same law does not regulate the procedure of its implementation. Thus, it becomes obvious that regardless of the type and scale of the organization's activity "there should be in a focus of attention the clearly structured, streamlined, flexible and timely responsive to changes system of the accounting (SBU) and internal control (ICS)" (Miroshnichenko and Zubareva, 2015). The state actively regulates the activity of agricultural areas. The implementation of the state policy in the field of the sustainable development of rural areas for the period up to 2020 is shown below.

Figure 1. Stages of the implementation of the state policy in the field of the sustainable development of rural areas for the period up to 2020 (Sudakova, 2016)

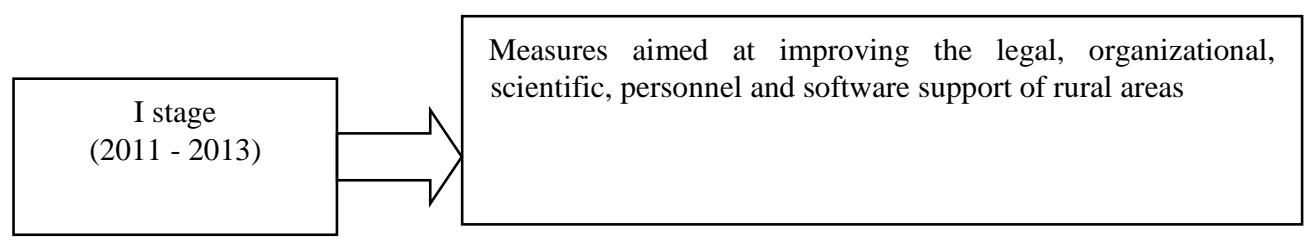

\begin{tabular}{|c|}
\hline II stage \\
(2014-2020)
\end{tabular}$\quad$\begin{tabular}{l}
$\begin{array}{l}\text { The growth of resource support for the development of rural } \\
\text { areas on the basis of strengthening the agricultural sector, } \\
\text { diversification and the development of the whole rural } \\
\text { economy, increasing the tax base of the rural development and } \\
\text { the financial basis of the local self-government, the general } \\
\text { economic growth and strengthening of the state support for } \\
\text { the rural areas within the framework of the proposed Federal } \\
\text { target program for the sustainable development of rural areas } \\
\text { for } 2014-2017, \text { taking into account its prolongation until } \\
2020 .\end{array}$ \\
\hline
\end{tabular}

Within the implementation of state policy, agricultural organizations should strive to improve their efficiency and effectiveness of their activity through the introduction of modern tools. When setting up the internal control system, agricultural companies independently develop rules of its organization within the current legal framework, as well as based on industry characteristics, scale, methods of production management, the range of products and other factors. After analyzing the definitions of Russian and foreign scientists, as well as interpretations in normative-legal acts, all definitions should be bundled into two main groups:

1. Within the framework of a narrow approach, the internal control system should be interpreted as a procedure organized by the management of the organization, 
focused on achieving the goals set by the commercial company and improving the efficiency of its activity, i.e. as one of the management stages.

2. Within the framework of a broad approach the internal control system should be understood as a constant process due to the organizational structure of the company.

For the formation of the effective internal control system it is necessary to consider the following factors:

1. form of ownership;

2. set of activities;

3. industry specifics;

4. form of taxation;

5. organizational structure;

6. defined business processes.

One of the fundamental factors affecting the internal control system is industryspecificity, especially since agriculture is quite a specific type of activity. The branch specificity of each concrete commercial organization is in features of its production and economic activity characterising the companies of this branch (Sudakova, 2016).

The main prerequisites for the intensive development of agriculture in Russia are:

- "diversity of soil cover;

- mostly flat nature of the territory;

- availability of human resources and a strong scientific base;

- chemicalization, mechanization and automatization of agricultural industry" (Vechirko and Tarasyuk, 2016).

The volume of agricultural production of commodity producers (agricultural organizations, peasant (farmer) farms, households), according to official data of the Federal state statistics service in 2017 in current prices, according to preliminary estimates, is 5654.01 billion rubles.

In the statistical collection of Rosstat for 2017, it is noted that annually in the period from 2010 to 2016, agricultural production in the Russian Federation is growing at a good pace (annual growth is an average of 12\%). According to the state program for the development of agriculture for the period from 2013 to 2020, it is planned to increase the average annual growth rate of gross agricultural output up to $2.5 \%$. Agricultural production is shown in Table 1. 
Table 1. Production of output of agriculture, $m \ln R U B(R R, 2017)$

\begin{tabular}{|l|c|c|c|c|c|c|c|}
\hline & \multicolumn{7}{|c|}{ years } \\
\cline { 2 - 8 } & 2010 & 2011 & 2012 & 2013 & 2014 & 2015 & 2016 \\
\hline $\begin{array}{l}\text { The Russian } \\
\text { Federation, } \\
\text { including }\end{array}$ & 2587751 & 3261695 & 3339159 & 3687075 & 4319050 & 5164877 & 5505755 \\
\hline
\end{tabular}

In 2017, in comparison with 2016, there is a trend of decline in agricultural production in Russia (Figure 2).

Figure 2. Dynamics of the agricultural production growth in Russia, \%

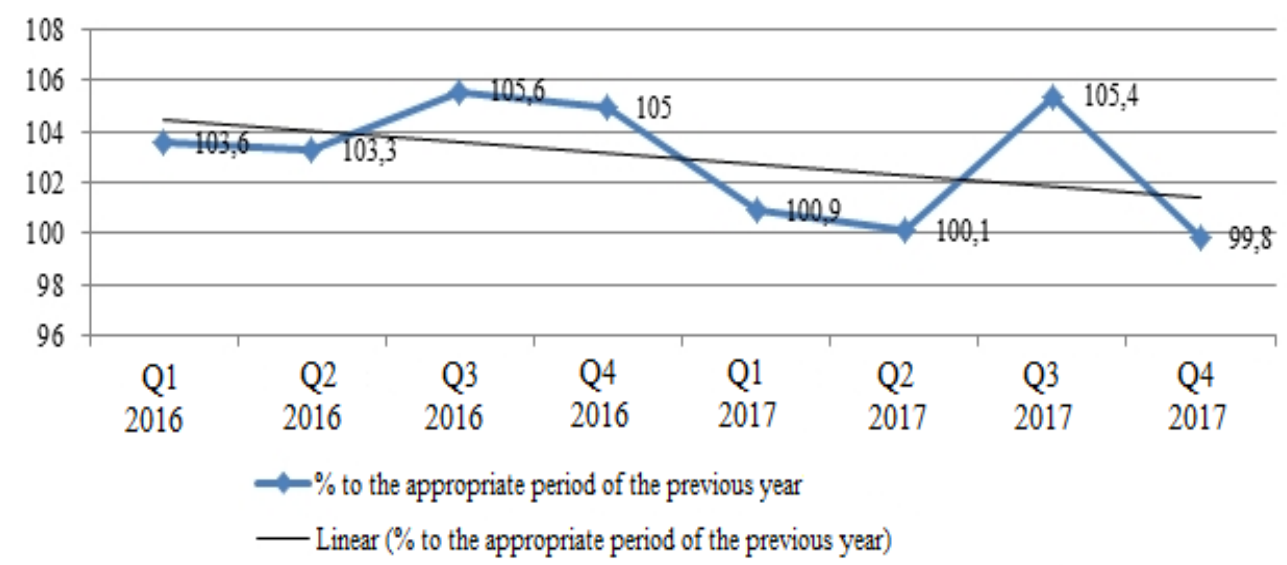

Agriculture is an industry divided into crop and livestock. Crop production is a fundamental industry that produces raw materials to produce food and feed for Pets. The main crop, which occupies most of the acreage of the globe, is grain, the most widespread among which are wheat, rice, corn, rye and oats. According to the official data of the Ministry of agriculture in the context of subjects of the Russian Federation on November 10, 2017 there are collected crops from the area of 45.6 million hectares. In 2017, 137.2 million tons of grain were collected, in 2016 - 120.7 million tons. Table 2 presents information on the collection of crops for 2016-2017.

On December 1, 2017 grain reserve in Russia was 52.6 million tons, that is $15.8 \%$ more compared to 1.12.2016. It must be admitted that "in 01.02.2018 (Rosstat) grain reserves in agricultural, procurement and processing organizations (excluding small forms) in Russia are 42.2 million tons, which is 6.6 million tons $(+18.7 \%)$ more than on February 1, 2017. Figure 3 shows agricultural producers across Russia, where grain stocks have been increasing every year. This trend is associated with a decrease in grain exports due to sanctions against the Russian Federation. 
Table 2. Data of agribusiness management bodies on gathering crops in Russian Federation

\begin{tabular}{|l|c|c|c|c|c|c|}
\hline \multirow{2}{*}{ Nume of rural } & \multicolumn{3}{|c|}{ During 2016г. } & \multicolumn{3}{c|}{ During 2017г. } \\
\cline { 2 - 7 } & $\begin{array}{c}\text { collected } \\
\text { from the } \\
\text { area, } \\
\text { million } \\
\text { hectares }\end{array}$ & $\begin{array}{c}\text { processed, } \\
\text { million } \\
\text { tons }\end{array}$ & $\begin{array}{c}\text { at yield, } \\
\text { C/ha }\end{array}$ & $\begin{array}{c}\text { collected } \\
\text { from the } \\
\text { area, } \\
\text { million } \\
\text { hectares }\end{array}$ & $\begin{array}{c}\text { processed, } \\
\text { million } \\
\text { tons }\end{array}$ & $\begin{array}{c}\text { at yield, } \\
\text { C/ha }\end{array}$ \\
\hline Wheat & 27,4 & 75,8 & 27,9 & 27,4 & 88,0 & 32,2 \\
\hline Barley & 7,8 & 19,1 & 23,5 & 7,8 & 21,8 & 28 \\
\hline Grain Maize & 2 & 10,5 & 56,4 & 2 & 10 & 50,1 \\
\hline Table & 175,9 & 1,2 & 66,1 & 175,9 & 1,1 & 63,7 \\
\hline $\begin{array}{l}\text { Sunflower } \\
\text { Grain }\end{array}$ & 5,5 & 10,1 & 15,8 & 5,5 & 8,5 & 15,4 \\
\hline Soy & 2,4 & 3 & 15,5 & 2,4 & 3,5 & 15 \\
\hline Rape & 903,9 & 1,1 & 12,1 & 903,9 & 1,6 & 17,3 \\
\hline Fibre flaxbrit & - & 45,2 & - & - & 40,9 & - \\
\hline Sugar beet & 1,1 & 46,7 & 459,9 & 1,1 & 46,6 & 429,1 \\
\hline Potato & 269,2 & 6,8 & 216,9 & 269,2 & 6,3 & 235,3 \\
\hline Vegetable & 148,8 & 4 & 242,1 & 148,8 & 3,7 & 247,4 \\
\hline
\end{tabular}

Figure 3. The graph of grain stocks in Russia in 01.12.2017 (AB-Centre, 2018)

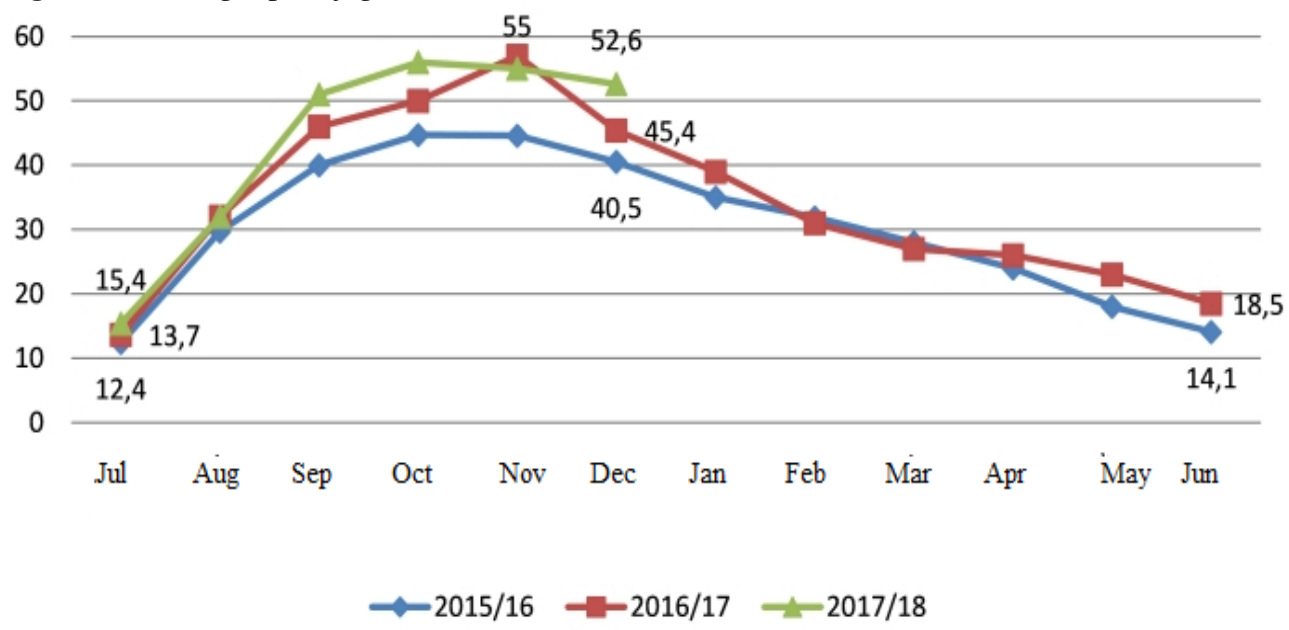

Exports of food products and agricultural raw materials in January-September 2017 amounted to 14009.8 million dollars. according to the information of the Ministry of agriculture of the Russian Federation, which is $19.0 \%$ more than in 2016. The dynamics of grain export growth for the period from 2015 to early 2018 is shown in Figure 4. 
Figure 4. Grain exports from Russia (thousand tons) (Rosstat AHF, 2018)

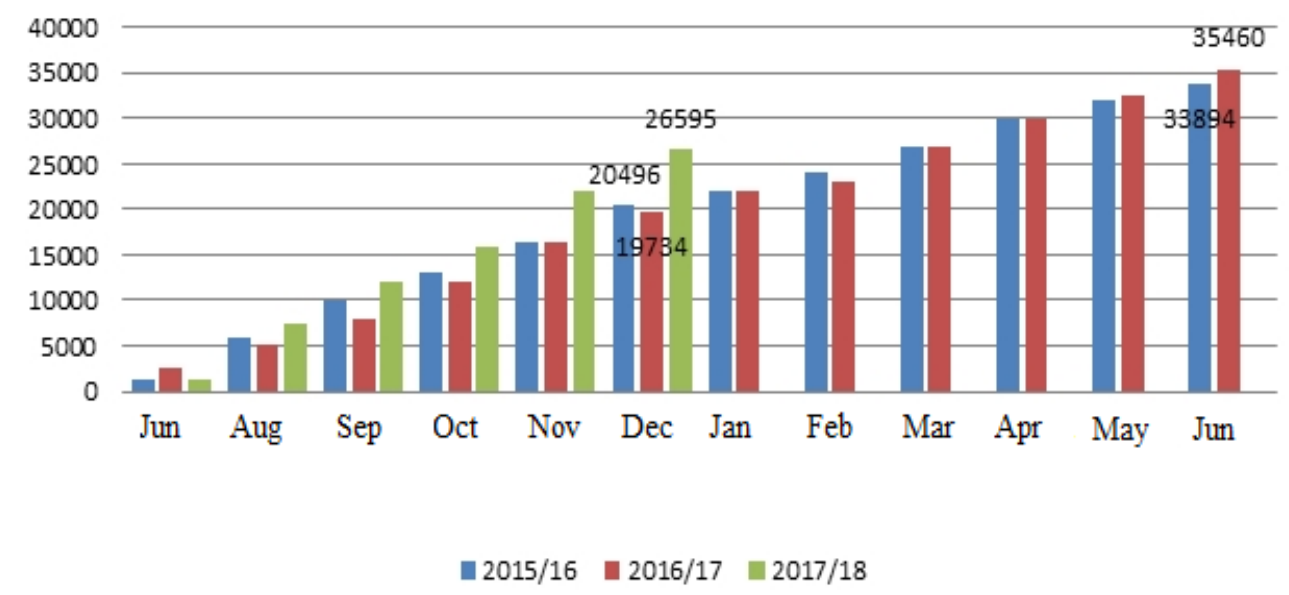

At the same time, the Resolusion of the government of the Russian Federation from July 14, 2012 № 717 "On the state program for the development of agriculture and regulation of markets of agricultural products, raw materials and food for 2013 2020" clearly sets out the main targets and indicators that should guide the agricultural sector, presented in Table 3 .

Table 3. Projected indicators of the implementation of the state program of the development of agriculture and regulation of markets of agricultural products, raw materials and food for 2013-2020

\begin{tabular}{|l|c|}
\hline \multicolumn{1}{|c|}{ Indicators } & $\begin{array}{c}2020 \text { year } \\
\text { to 2022 year }\end{array}$ \\
\hline $\begin{array}{l}\text { Index of agricultural production in farms of all categories ( in } \\
\text { comparable prices), \% }\end{array}$ & 124,8 \\
\hline $\begin{array}{l}\text { Index of crop production in farms of all categories ( in comparable } \\
\text { prices), } \%\end{array}$ & 129,2 \\
\hline $\begin{array}{l}\text { Index of livestock production in farms of all categories ( in } \\
\text { comparable prices), }\end{array}$ & 119,7 \\
\hline Index of food production, including beverages \% & 132,5 \\
\hline $\begin{array}{l}\text { The index of physical volume of investments (including } \\
\text { subsidies)\% }\end{array}$ & $\begin{array}{c}138,0 \\
\text { (up to15\%) }\end{array}$ \\
\hline $\begin{array}{l}\text { Profitability of agricultural organizations (including subsidies), } \\
+10508 \\
\text { (up to 25 } \\
500)\end{array}$ \\
\hline $\begin{array}{l}\text { The average monthly nominal salary in agriculture (on the } \\
\text { agricultural organizations not relating to subjects of small } \\
\text { business), RUB }\end{array}$ & \begin{tabular}{c}
135,3 \\
\hline The index of labor productivity,\%
\end{tabular} \\
\hline The number of high-performance workplaces, thousand units \\
\hline Share of costs for the purchase of energy resources in the structure & $-0,5$ pts ** \\
\hline
\end{tabular}


of costs for the main production of agricultural products, $\%$

(up to 9,4 )

*- in 2020 relating to 2013

**- in 2020 relating to 2015

This program lays down the main directions of the development of the agricultural sector:

- achievement of food security in Russia;

- improving the efficiency of the agricultural organization;

- improving the competitiveness of agricultural products in the domestic and foreign markets;

- greening of production;

- in the social sphere (the development of rural infrastructure);

- in the institutional sphere (the development of product subcomplexes and territorial clusters);

- in scientific and human resorses spheres (the formation of innovative agroindustrial complex).

These directions are linked to the target indicators and indicators of the development of the agricultural sector. After analyzing the industry features in agriculture, investigated by different scientists and practitioners, it should be noted that all researchers in this area take into account different number and different types of features.

However, having made a review, we came to the conclusion that some of the features are noted by almost all the scientists. These include: climatic conditions of agricultural production, the presence of seasonal factors of agricultural production, the main means of production - land, the period of production does not coincide with the period of its implementation. Other industry features in agriculture are:

1. The influence of state policy, through the creation of state programs for the development of the agricultural sector to the level of production, price dynamics, employment.

2. Special level and conditions of the use of equipment in the field of agriculture.

3. Method of product evaluation: accounted for the planned prime cost, at the end of the year is adjusted to the actual cost by the "red storno" or "re-evaluation".

4. Crop and livestock production are characterized by several types of products, some of which are used for their own consumption.

When building an effective internal control system, the administration of the agricultural organization must ensure:

- the formation of reliable, complete, relevant and timely information on the status of the agricultural company based on the use of accounting and non-accounting data, which is necessary for the successful management; 
- the formation of the document management system at an agricultural enterprise, which contributes to the preservation of its material and technical base and resource potential;

- the determination of the system of criteria for the effectiveness of the agricultural enterprise and the strategies to achieve them; the formation of a reliable accounting system, which serves as an information system of the enterprise, based on the use of the communication system between the divisions of the enterprise, and provides assistance in centralized or decentralized management decision-making process (Klimenko, 2015).

Having studied the different points of view of domestic scientists who distinguish all kinds of narrow types of problems of the internal control system, as well as sectoral features of agriculture, we made a conclusion that in modern conditions it is advisable to identify the following enlarged groups of problems:

1. normative-legal;

2. organizational-methodical;

3. informational;

4. methodological;

5. software and hardware.

The normative and legal problem is that there is no sectoral regulation of the internal control in the agricultural organizations, there is no a single legal methodology of its organization and normative legal acts in the field of reporting data.

Within the framework of this problem, we identify the following issues:

1. The lack of comprehensive sectoral normative and legal regulation of the internal control system in agricultural organizations;

2. The lack of regulatory consolidation of a single methodology for the formation of internal control system of the entire agricultural company and of allocated segments (business processes).

Thus, in order to solve problems of the legal regulation of the internal control system at agricultural enterprises, it is necessary to analyze the normative and legal regulation of the internal control system of agricultural enterprises.

Based on the existing legal acts in the field of the internal control system, each agricultural organization should develop and approve internal regulations that organize internal control, taking into account the industry specifics and characteristics of a particular organization. Also according to Kizilov and Bogatyi (2013), who claimed that "the concept of the organization and further development of the internal control shall be reflected in the conceptual standards which are supplemented and concretized by the organizational competence standards disclosing the main functions, the rights, duties of the divisions performing 
accounting and control functions and the employees working in them ". Kizilov and Bogatyi (2013) believe that "the conception of the formation and further development of the internal control should be reflected in the conceptual standards, which are supplemented and specified by organizational and competence standards, revealing the main functions, rights, duties of the units performing accounting and control functions and employees working in them".

Organizational and methodological group of problems of the internal control system in agricultural organizations is associated with the process of unification and standardization of the formulation and implementation of the internal control system, as well as the introduction of the regulations of the internal control system and methods of its implementation. Also in this group it is important to highlight the regulations related to the evaluation of the effectiveness of the internal control system.

Within the framework of organizational and methodological support, it is necessary to highlight problems associated with training and advanced training in the field of formulation and implementation of the internal control system taking into account agricultural specifics. Creation and distribution of accounting training programs available for a wide range of employees, as well as advanced training on the formulation of the internal control system, taking into account the sectoral agricultural specifics, which would be supported by the state. It is important to promote the status and popularize the profession of modern controller-accountant through the conduct of all-Russian and international professional competitions.

Information problems associated with the development and application of the internal regulations of the internal control system in agricultural organizations, on the basis of state-approved standards. These internal regulations would structure and specify in more detail, based on different groups of factors, the procedure for implementing an effective internal control system in agricultural organizations. All internal regulations in the field of the internal control system should be developed on the basis of industry characteristics of agricultural organizations that affect the accounting system, financial reporting.

Methodological problems of the formation of the internal control system in agricultural organizations focused on the optimal combination of basic principles, methods and techniques of organization and functioning of the internal control in agricultural organizations.

Now, there are no uniform "principles of the internal control for all types and forms of its implementation, although they can be identified on the basis of the purpose, tasks and practices of monitoring activities" (Serebryakova, 2010). For the effective organization of the internal control system, it is necessary to rely on the principles of its establishment and functioning. 
Methods of assessment of the internal control system can be quantitative and qualitative. The quantitative methods of assessment of the internal control system include mathematical models (the average mathematical expectation of the event and/or result), expert evaluation, calculation of indicators characterizing the costs of the organization and functioning of the internal control system.

Qualitative methods of the assessment of the internal control system are survey (interviewing), maturity models, standards, norms, best practices. The main methodological principles of the formation and effective functioning of the internal control system in agricultural organizations are:

1. "General scientific methods (deduction, induction, analogy, modeling);

2. Own empirical methodical methods of control (inventory, counter-check, formal arithmetic and logical check, way of the return account, comparison, scanning, control measurements of works, examination, poll, tracing);

3. Specific techniques (economic and mathematical methods, methods of probability theory and mathematical statistics, econometric methods, methods of economic analysis)".

Program and technical problems of the organization of the internal control system in agricultural organizations are associated with the use of a variety of auxiliary information and legal systems during setting the internal control (Consultant Plus, guarantor, Code), as well as software products which contribute to the optimization and improvement of the internal control system in agricultural organizations.

\section{Regional Public and Private Partnership and the Investment Projects}

Based on the research of modern problems there was revealed the interrelation of the general and private problems of the internal control system in the agricultural organizations which is given in Figure 5. All the opinions and points of view of domestic scientists and practitioners indicate numerous, diverse problems of the internal control system, considering the sectoral characteristics of agriculture, in the transition to international standards that affect all kinds of regulatory areas. Having considered the variety of problems of the internal control system in agricultural companies, we drew the conclusion about the need and the possibility to group them into legal; organizational and methodological; information; methodological; software and hardware subproblems. The solution of the mentioned general and specific issues will form an effective internal control system in agricultural companies, which will make it possible to achieve strategies of the development in a competitive environment, to retain and efficiently use the resources and capacity of the organization, identify and effectively manage various types of risks in the company, "to create a system for the information support at all levels of management proper to modern permanently changing economic conditions, possible to timely adapt the functioning of the organization to changes in the internal and external environment". 
Figure 5. Interrelation of general and particular problems of the internal control system in agricultural organizations

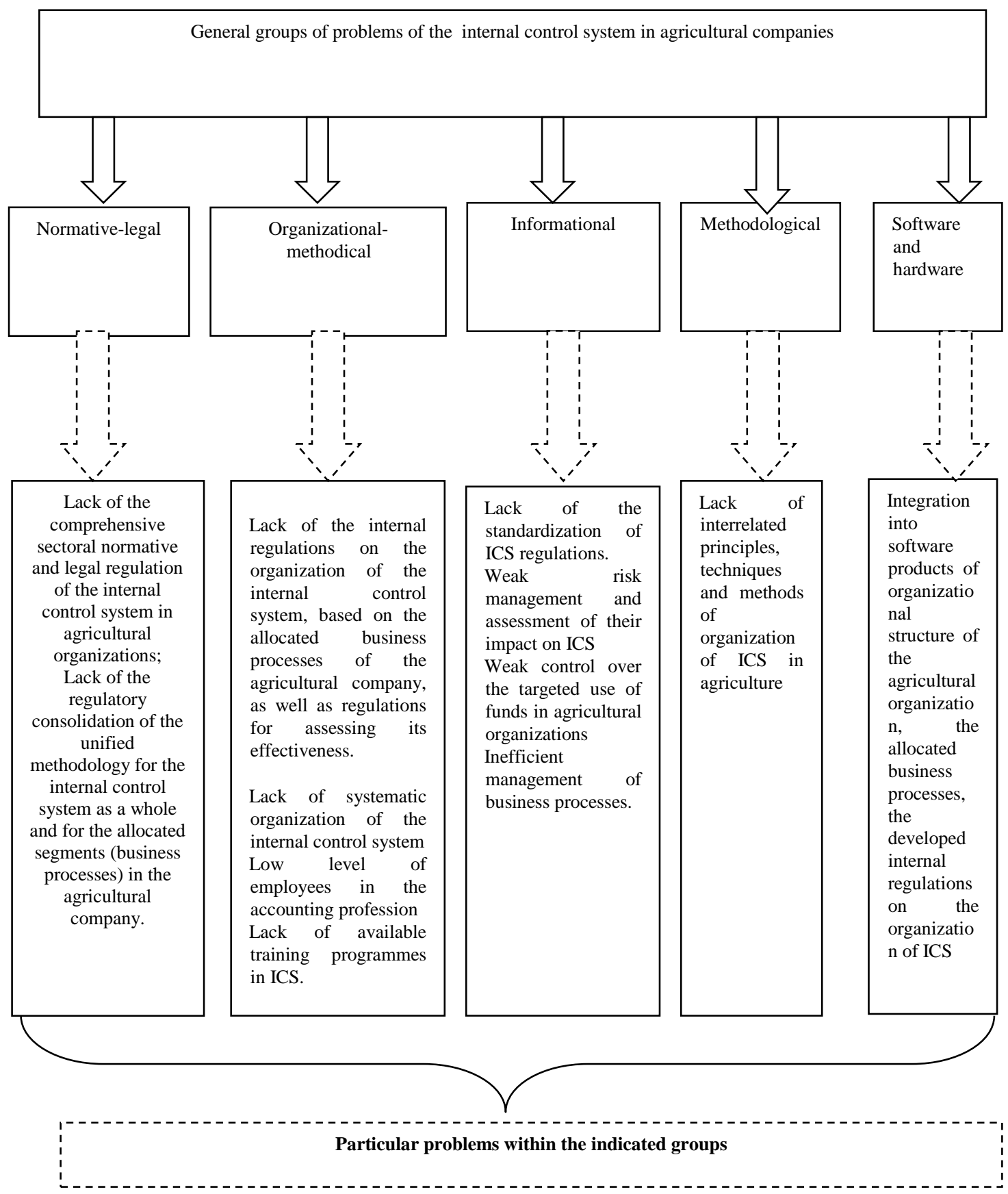




\section{Conclusion}

The research will allow to reveal industry features of the internal control system in agriculture which should be considered at the development of the effective internal control system that in turn will allow to reveal reserves of the growth and deviations from the approved norms and standards. The authors argued following main features: climatic conditions of agricultural production, the factor of seasonality of agricultural production, land as the main means of production, the period of production does not coincide with the period of production.

Other industry features in agriculture are: the influence of the state policy, through state programs of the development of agricultural branch on the level of production, dynamics of the prices, employment of the population; special level and conditions of the use of equipment in agriculture, a method of the assessment of production; it is accounted for the planned cost price, at the end of the year it is corrected to the actual cost price by the method of "red storno" or "dootsenka»; crop and livestock production is characterized by several types of products, some of which are used for their own consumption. On the basis of the study we have identified different points of view of domestic scientists, which indicate narrow types of problems of the internal control system in modern conditions: legal; organizational and methodological; informational; methodological; software and hardware.

\section{References:}

AB-Centre. 2018. Expert-analytical center of agribusiness "AB-Center". C-P.

AHF Rosstat. 2018. Agriculture, Hunting and Forestry. Official Data of Rosstat, available at: http://www.gks.ru/wps/wcm/connect/rosstat_main/rosstat/ru/statistics/enterprise/econ omy/

Alekseeva, I.V., Mosentseva, V.A. 2017. Approaches to the Organization of the Internal Control System. In Actual Directions of the Development of Accounting, Analysis and Audit in the Modern Economy. Materials of the International Scientific-practical Conference, 10-13.

Antonova, E.V. 2012. Legal Regulation of the Internal Control in the Russian Federation. Law and Policy, 12(156).

Baryshnikov, N.G., Samygin, D.Yu. 2013. Diagnosis of Forecasts of the Development of Agriculture. Niva of Volga Region, 3(28).

Kizilov, A.N., Bogatyi, D.V. 2013. Methodological Approaches to the Development of the Conceptual Standard "Policy in the Internal Control System" in commercial organizations. Modern Problems of Science and Education, 6, 465.

Klimenko, O.P. 2015. Organization of the Internal Control System of Current Biological Assets of Livestock. Actualscience, 1, 121-126.

Kolobaeva, A.A. 2016. Legal Regulation of Organization of Internal Financial Monitoring of Energy Companies. Scientific Forum: Innovation Science: materials of the I International scientific-practice conference. Moscow, Publishing House MCNO, 3946.

Labyntsev, N.T., Hechanova, N. N., Makarenko, E.N., Rich, I.N., Alekseeva, I.V., Sour, I. A., Shcherbakova, E. P., Chernov, A.Yu., Rabanco, I.A., Emelyanova, I.N. 2017. The 
Development of the Internal Audit of Business in Commercial Organizations. Rostovon-Don.

Miroshnichenko, T.A., Zubareva, O.A. 2015. Formation of the Internal Control System in Agricultural Organizations. Fundamental Research, 4-0, 229-233.

Moskvitin, G.I., Labusova, Y.G. 2015. The Role of Internal Control in the Enterprise Management System. Science Vector of TSU, Series: Economics and Management, 4(23).

RR. 2017. Regions of Russia. Socio-economic indicators. Collection of articles / Rosstat. M., 1402 p. http://www.gks.ru/free doc/doc 2017/region/reg-pok17.pdf

SD Concept. 2010. The Concept of the Sustainable Development of Rural Areas of the Russian Federation up to 2020: approved by decree of the Government of the Russian Federation № 2136-p from November 30.

Serebryakova, T.Yu. 2010. Risks of Organization and the Internal Economic Control. Moscow, INFRA-M, 111.

Storozhuk, T.M. 2006. Problems of the Assessment of Biological Assets. Proceedings of the II International Scientific-practical Conference. Kiev, October 19-20, 53-54.

Sudakova, A.E. 2016. Monitoring of the Position of Agriculture in Russia. Economic Analysis, Theory and Practice, 2 (449).

Vechirko, O.N. 2017. Features of the Development of Agriculture in the Republic of Crimea. Economics and agriculture, 6. 